\title{
Associations between milking technology, herd size and milk production parameters on commercial dairy cattle farms
}

\author{
Dorottya Ivanyos ${ }^{1}$, Attila Monostori², Csaba Németh², \\ István Fodor ${ }^{7}$, László Ózsvári ${ }^{*}$
}

\footnotetext{
${ }^{1}$ University of Veterinary Medicine Budapest, István u. 2., Budapest, Hungary

${ }^{2}$ Livestock Performance Testing Ltd., Dózsa Gy. út 58., Gödöllő, Hungary

*Corresponding author: ozsvari.laszlo@univet.hu
}

\section{Abstract}

The aim of the study was to survey the milking technology and to analyse the associations between milking parlour type, herd size, and milk production parameters on dairy cattle farms. The milking technology was surveyed by using a questionnaire in 417 Hungarian dairy herds with 177,514 cows in 2017 , and it was compared with their official farm milk production data. The surveyed farms were categorized according to their size (1-50, 51-300, 301-600, and >600 cows) and to their milking parlour types (herringbone, parallel, carousel, and others). The relationships were analysed by multivariate linear models, one-way ANOVA, and Fisher's exact test. Pairwise comparisons were performed by Tukey's post hoc tests. The prevailing type of milking parlour was herringbone (71.0\%), but on larger farms the occurrence of parallel and carousel parlours increased $(p<0.001)$. The number of milking stalls per farm increased with herd size $(p<0.001)$. Farms with herringbone parlour had significantly smaller number of milking stalls than that of parallel $(p=0.022)$ and carousel $(p<0.001)$ parlours, and the cows were mostly milked two times, while in carousel milking parlours mostly three times a day. As the herd size increased, so did daily milk yield $(p<0.001)$ and daily milk production per cow $(p<0.001)$. Herd size was associated with somatic cell count $(p<0.001)$. The type of milking parlour showed significant association with daily milk yield $(p=0.039)$ and dairy units with herringbone milking system had the lowest milk quality. Our findings show that herd size has greater impact on milk production parameters than milking technologies.

Key words: dairy, milking technology, herd size, milk production, somatic cell count 


\section{Introduction}

The milking equipment and routine greatly influence the milk production and profitability on dairy farms. The installation of a milking system entails serious costs and the investment returns only with an adequate amount of milk production (O'Brien et al., 2012). In addition, the milking technology greatly influences the organization of animal movements (e.g. moving cows to the milking parlour, selecting cows for treatment, regrouping), the selection of milking routines, the quality of human labour, the hygiene and the technical efficiency of milking equipment during the milking period (Tyapugin et al., 2015). Technological diversity has an impact on milk production, particularly on milk quality. In case of a milking equipment failure, the economic losses caused by the milk quality and the damage of animal health and wellbeing, as well, should be taken into account (Rasmussen et al., 2002; Tyapugin et al., 2015).

Grouped by the way of housing, bucket machine, tank truck and pipeline milking machine can be used in tied housing systems, while stable flooring (tandem, herringbone, parallel, polygon), moving flooring (carousel, head carriage) milking systems and milking robots can be used in loose housing systems (Béri, 2011). It is economically efficient on farms with less than 30 cows to use bucket machine milking. If the size of a herd varies between 30-50 cows, it is more efficient to use milking systems with a milk pipeline in the cowshed and non-automated equipment. Larger dairy herds require a milk pipeline and automated equipment or a milking parlour (Nipers et al., 2016). The modernisation of milk production is directly associated with an increase in herd size, which allows the farm to efficiently exploit the newest technologies and rationally use its labour (Nipers et al., 2016).

The number of milking stalls can also affect the efficiency of the milking system. Milking time increases along with the increase in the number of milking stalls (Priekulis and Kurgs, 2010). However, milking duration and milk yield are not affected by the milking stall number or parlour size in different phases of lactation (O'Brien et al., 2012). According to Priekulis and Kurgs (2010) the herringbone system has the lowest efficacy, while the carousel is the most effective one. From the economic point of view, the operation of a herringbone milking system is the most economical for herds consisting of up to 400 cows. However, it is more beneficial to use a carousel milking system for herds consisting of 400 to 800 cows.

Roza et al. (2015) found that the technological standard of machinery, equipment and infrastructure on dairy farms influenced the milk production parameters (milk protein content, milk fat content, total bacterial count). Herd size can also have an impact on milk production. Krpálková et al. (2016) found that the highest milk producing herds ( $\geq 9000$ $\mathrm{kg} /$ lactation) had the largest size $(809.07 \pm 100.11$ cows). Milk protein and milk fat content did not differ significantly by herd size. Nevertheless, the highest milk protein and fat contents were found on the largest farms. According to Jago and Berry (2011) there is no association between herd size and milk production, but milk protein and milk fat content increases with herd size.

The aim of the study was to survey the milking technology and to assess the relationship between the milking technology, the herd size, and the milk production parameters on the Hungarian commercial dairy farms.

\section{Materials and methods}

The milking technology (type of milking parlour, number of milking stalls, number of daily milkings, and daily milking time) was surveyed through personal interviews by using a questionnaire on 417 commercial Hungarian dairy farms with 177,514 cows in 2017. It was compared with the official milk production data (average daily milk yield, average daily milk production per cow, average somatic cell count [SCC]) of the farm in March 2017. On the surveyed farms milk performance tests are conducted monthly, based on individual milk samples from all milking cows. In the surveyed dairy units, the average number of cows ( \pm standard deviation) was $425.7 \pm 372.3$ per farm, the average daily milk production per cow $24.0 \pm 6.2 \mathrm{~kg} /$ day, the average daily milk yield $27.6 \pm 6.3 \mathrm{~kg} /$ day and the average SCC $405.030 \pm 183,890 \mathrm{cell} / \mathrm{mL}$. The surveyed farms were categorized according to herd size (Group 1: 1-50 cows, Group 2: 51-300 cows, Group 3: 301-600 cows, and Group 4: >600 cows) and to their milking parlour 
types (herringbone, parallel, carousel, and others including pipeline, tandem, and robot milking systems). The obtained data were processed in MS Excel 2013 (Microsoft Corporation, Redmond, WA, USA).

The relationship between milking technology, herd size and milk production parameters was analysed by multivariate linear models. In each model, herd size and the type of milking parlour were included as explanatory variables, whereas one of average daily milk yield, average daily milk production per cow, SCC, or the number of milking stalls was included as the dependent variable. The association of herd size and type of milking parlour was analysed by one-way ANOVA. Pairwise comparisons were performed by Tukey's post hoc tests. The relationship between herd size, the type of milking parlour and the number of milkings was analysed by Fisher's exact test. Statistical analyses were performed in R version 3.5.1. (R Core Team, 2018).

\section{Results and discussion}

\section{Milking parlour types}

The number of farms was 40 (9.6\%) in Group 1, 140 (33.6 \%) in Group 2, 142 (34.0 \%) in Group 3 and 95 (22.8\%) in Group 4. The most commonly used type of milking parlours was the herringbone (296 farms, $71.0 \%$ ), followed by the parallel (62 farms, $14.9 \%$ ), the carousel (40 farms, $9.6 \%$ ) and others (19 farms, $4.6 \%$ ). Herds with different milking parlour types significantly differed in herd size $(p<0.001)$, except for the parallel vs. other parlour types. The most common type of milking parlours was the herringbone, but as the herd size increased, so did the occurrence of parallel and carousel parlour systems (Figure 1). The least common milking parlour type was the tandem (2.8\%).

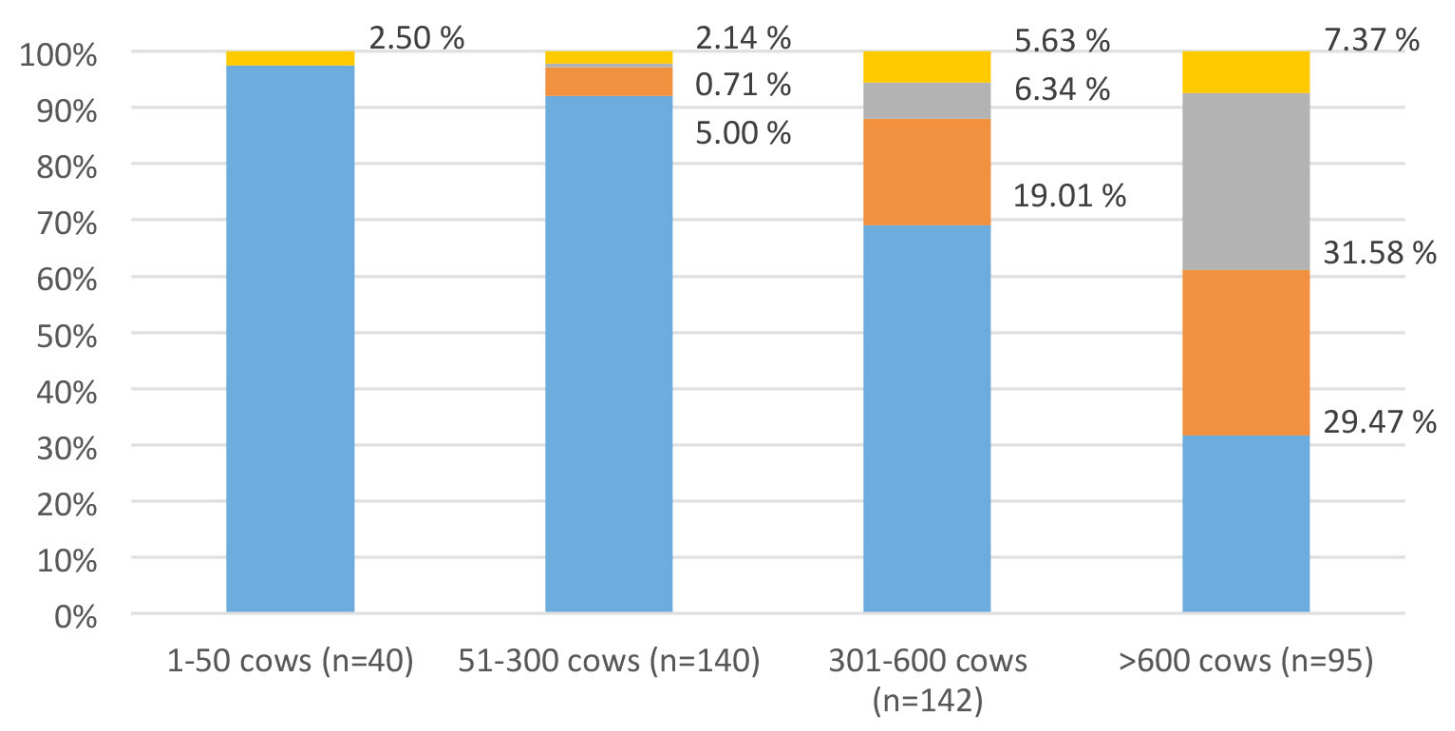

werringbone $\square$ parallel $\square$ carousel $\square$ other

FIGURE 1. The distribution of milking parlour types according to herd size $(n=417)$

The distribution of milking parlour types according to herd size in Hungary was very similar to the Latvian situation, where the most common milking system was herringbone in the dairy units (Nipers et al., 2016). At the same time parallel, tandem, and carousel milking technology were also used, but in the last decade an intense implementation of robot milking systems started, as well. Nipers et al. (2016) recommended a separate parlour over 200 cows. However, our results showed that even the Hungarian farms with smaller number of cows have already used separate milking parlours.

Table 1 shows the average cow number, the average daily milk production per cow, the average daily milk yield and the average SCC in the different herd size groups according to milking parlour types. 
The number of milking stalls and daily milkings, and the milking time

The number of milking stalls varied from 2 to 80 on the surveyed farms depending on the number of cows and the type of milking parlour.

The number of milking stalls per farm increased with the number of cows ( $<<0.001$, Table 2$)$.
Farms with herringbone parlour had significantly smaller number of milking stalls than the farms with parallel $(p=0.022)$ and the carousel $(p<0.001)$ parlours. The average number of milking stalls of carousel parlours tended to be larger than that of parallel parlours ( $p=0.062$, Table 3 ).

TABLE 1. Milk production parameters according to herd size and type of milking parlour ( $n=417)$

\begin{tabular}{|c|c|c|c|c|c|c|}
\hline Group & Parlour type & $\begin{array}{l}\text { Number } \\
\text { of farms }\end{array}$ & $\begin{array}{l}\text { Average cow } \\
\text { number }\end{array}$ & $\begin{array}{l}\text { Average daily } \\
\text { milk production } \\
\text { per cow (kg/day) }\end{array}$ & $\begin{array}{l}\text { Average daily } \\
\text { milk yield } \\
\text { (kg/day) }\end{array}$ & $\begin{array}{l}\text { Average SCC } \\
\left(\times 10^{3} \text { cell } / \mathrm{mL}\right)\end{array}$ \\
\hline \multicolumn{7}{|c|}{$1-50$ cows } \\
\hline & Herringbone & 39 & $28.0 \pm 14.2$ & $17.5 \pm 6.0$ & $20.7 \pm 5.9$ & $406.9 \pm 247.0$ \\
\hline & Other & 1 & $22.0 \pm 0.0$ & $12.5 \pm 0.0$ & $15.2 \pm 0.0$ & $270.0 \pm 0.0$ \\
\hline \multicolumn{7}{|c|}{$51-300$ cows } \\
\hline & Herringbone & 129 & $165.6 \pm 72.5$ & $21.0 \pm 5.3$ & $24.6 \pm 5.4$ & $446.9 \pm 207.8$ \\
\hline & Parallel & 7 & $188.0 \pm 84.5$ & $22.9 \pm 5.6$ & $26.7 \pm 5.1$ & $388.1 \pm 205.2$ \\
\hline & Carousel & 1 & $152.0 \pm 0.0$ & $17.2 \pm 0.0$ & $20.0 \pm 0.0$ & $368.0 \pm 0.0$ \\
\hline & Other & 3 & $219.0 \pm 93.9$ & $22.7 \pm 1.8$ & $26.7 \pm 1.5$ & $345.0 \pm 185.6$ \\
\hline \multicolumn{7}{|c|}{ 301-600 cows } \\
\hline & Herringbone & 98 & $419.9 \pm 79.6$ & $25.5 \pm 4.9$ & $29.0 \pm 4.9$ & $432.4 \pm 160.6$ \\
\hline & Parallel & 27 & $485.6 \pm 65.0$ & $27.8 \pm 4.4$ & $31.3 \pm 4.4$ & $347.7 \pm 153.7$ \\
\hline & Carousel & 9 & $477.1 \pm 91.4$ & $25.1 \pm 5.0$ & $29.3 \pm 4.8$ & $356.0 \pm 131.2$ \\
\hline & Other & 8 & $437.1 \pm 62.9$ & $24.3 \pm 6.0$ & $27.9 \pm 6.2$ & $453.8 \pm 133.4$ \\
\hline \multicolumn{7}{|c|}{$>600$ cows } \\
\hline & Herringbone & 30 & $851.2 \pm 297.7$ & $26.9 \pm 6.1$ & $30.6 \pm 5.8$ & $371.9 \pm 151.9$ \\
\hline & Parallel & 28 & $936.8 \pm 324.3$ & $29.4 \pm 3.6$ & $33.4 \pm 4.3$ & $342.2 \pm 101.5$ \\
\hline & Carousel & 30 & $1,052.2 \pm 486.0$ & $28.8 \pm 4.1$ & $32.3 \pm 4.2$ & $313.3 \pm 111.8$ \\
\hline & Other & 7 & $1,075.6 \pm 314.1$ & $30.4 \pm 2.8$ & $34.0 \pm 2.8$ & $321.0 \pm 225.0$ \\
\hline
\end{tabular}

TABLE 2. Average number of milking stalls according to herd size $(n=417)$

\begin{tabular}{l|l|l}
\hline & $\begin{array}{l}\text { Number } \\
\text { of farms }\end{array}$ & $\begin{array}{l}\text { Average number } \\
\text { of milking stalls }\end{array}$ \\
\hline $1-50$ cows & 40 & $9.5 \pm 6.3^{\mathrm{a}}$ \\
\hline $51-300$ cows & 140 & $15.6 \pm 6.4^{\mathrm{b}}$ \\
\hline $301-600$ cows & 142 & $25.7 \pm 7.1^{\mathrm{c}}$ \\
\hline$>600$ cows & 95 & $41.3 \pm 13.2^{\mathrm{d}}$ \\
\hline
\end{tabular}

a, b, cd Groups with different superscripts differ significantly $(p<0.05)$
TABLE 3. Average number of milking stalls according to the type of milking parlour $(\mathrm{n}=417)$

\begin{tabular}{l|l|l}
\hline & $\begin{array}{l}\text { Number } \\
\text { of farms }\end{array}$ & $\begin{array}{l}\text { Average number } \\
\text { of milking stalls }\end{array}$ \\
\hline Herringbone & 296 & $19.8 \pm 10.3^{\mathrm{a}}$ \\
\hline Parallel & 62 & $32.9 \pm 10.1^{\mathrm{b}}$ \\
\hline Carousel & 40 & $41.9 \pm 12.2^{\mathrm{b}}$ \\
\hline Other & 19 & $30.4 \pm 13.3^{\mathrm{ab}}$ \\
\hline
\end{tabular}

a, b Milking parlour types with different superscripts differ significantly $(p<0.05)$. 
Our results showed that larger farms had larger number of milking stalls, on an average. As parallel and carousel milking parlours mostly occurred on larger farms that could explain these differences in the average number of milking stalls. As the number of milking stalls increases, the permeability of the parlour increases, and the operators' idle time decreases. Thus, the efficiency is supposed to improve, while knowing that the operators' effectiveness is influenced by a number of other factors, such as milking routine and average milk yield of cows (Edwards et al., 2013; O'Brien et al., 2012).
The number of stalls, which can be handled by an operator, largely depends on the milking routine that also affects the efficiency of milking. However, even a well-trained operator has a reduced performance after 2 hours of continuous work (O'Brien et al., 2012).

The number of daily milkings ranged from 2 to 4 , and the total milking time per day was 9.5 hours, on average on the surveyed commercial farms (Figure 2). Milking time is greatly influenced by the efficiency of the milking system and the herd size (Priekulis and Kurgs, 2010).

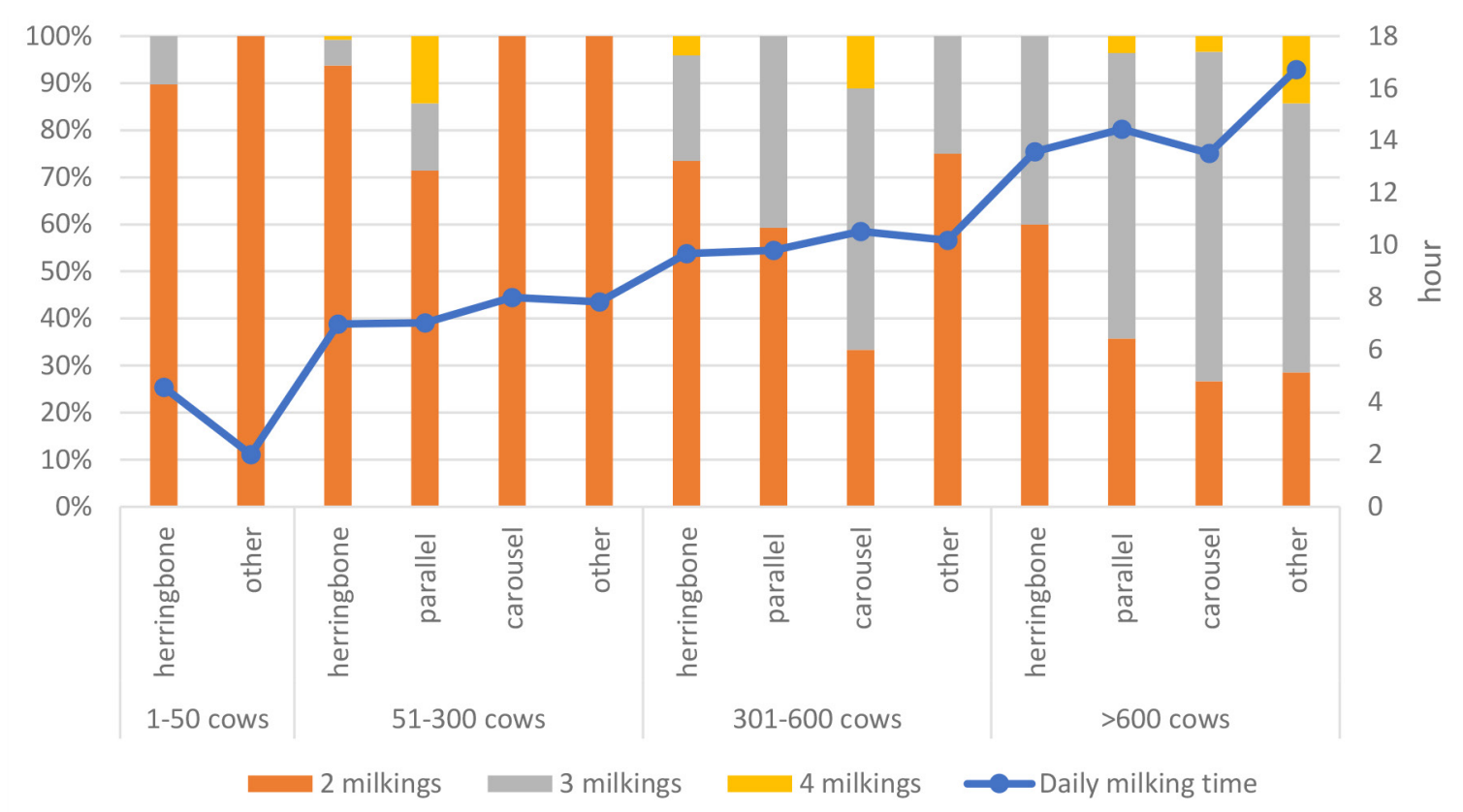

FIGURE 2. The number of milkings per day and the average milking time per day according to herd size and type of milking parlour

Herd size was significantly associated with the number of daily milkings ( $p<0.001)$, which corresponded with the results of Nipers et al. (2016). The number of daily milkings increased with herd size, thus, $60.0 \%$ of the farms with more than 600 cows milked the cows three or four times per day. The type of milking parlour was significantly related to the number of milkings per day $(p<0.001)$. On dairy farms with herringbone parlours the cows were mostly milked two times a day, but where parallel or carousel milking parlour was installed the occurrence of this milking practice diminished. On the majority of the surveyed farms using carousel milking parlour the cows were milked three times a day.

By applying proper milking technology and routine three milkings a day could result in higher milk production and smaller incidence of mastitis, but the operating costs are usually larger, which could finally decrease the profitability of the farm. Therefore, a thorough economic analysis is recommended before increasing the number of milkings from two to three times per day (Seres and Ózsvári, 2014). In Latvia $82.4 \%$ of the farms milked the cows twice a day, $17.6 \%$ three times daily. Farms that milked the cows three times a day reached up 
to $25 \%$ higher daily milk production with intensive feeding (Nipers et al., 2016).

\section{Associations between the type of milking parlour, herd size and milk production parameters}

Herd size was associated with the average daily milk production per cow $(p<0.001)$ and the average daily milk yield $(p<0.001)$. Along with the increased herd size, the average daily milk yield $(p<0.001)$ and the average daily milk production per cow $(p<0.001$, Table 4) increased, too. The herd size was significantly related to SCC $(p<0.001)$, with the largest farms having the best quality milk in terms of the somatic cell count. The lower milk production on smaller dairy farms can be explained with lower standards of housing, feeding, milking technology, and genetics (Rodrigues et al., 2005).

The type of milking parlour was related to the average daily milk yield $(p=0.039)$, and showed a tendency with average daily milk production per cow ( $p=0.062)$. Dairy farms using parallel milking parlours had significantly larger average daily milk production per cow $(p=0.033)$ and average daily milk yield $(p=0.019)$, than farms using herringbone parlour. Fahim et al. (2018) showed that cows, which favoured one side of the herringbone milking parlour, had a significantly higher milking average and lower milking time. The type of milking parlour tended to be associated with SCC $(p=0.061)$. Herringbone parlours resulted in the highest average SCC, although no significant differences were found between the different parlour types (Table 5). Since the milk quality is influenced by many other factors (such as age of the parlour, milking routine, udder hygiene, etc.) we cannot conclude that herringbone parlours do not provide the necessary conditions for milking, but the risk of producing milk with poorer quality may be higher. The average SCC on the Hungarian dairy farms is high regardless the herd size and milking technology, which has a detrimental impact on the milk production, as well (Ózsvári et al., 2003; Halasa et al., 2007; Pfützner and Ózsvári, 2017).

TABLE 4. Milk production parameters by herd size groups $(n=417)$

\begin{tabular}{l|c|c|c|c}
\hline & $\begin{array}{c}\text { Average } \\
\text { cow number }\end{array}$ & $\begin{array}{c}\text { Average daily milk } \\
\text { production per cow (kg/day) }\end{array}$ & $\begin{array}{c}\text { Average daily milk } \\
\text { yield (kg/day) }\end{array}$ & $\begin{array}{c}\text { Average SCC } \\
\left(\times 10^{3} \text { cell/mL) }\right.\end{array}$ \\
\hline $1-50$ cows & $28 \pm 14^{\mathrm{a}}$ & $17.32 \pm 5.97^{\mathrm{a}}$ & $20.55 \pm 5.90^{\mathrm{a}}$ & $403.43 \pm 244.72^{\mathrm{a}}$ \\
\hline $51-300$ cows & $168 \pm 72^{\mathrm{b}}$ & $21.08 \pm 5.30^{\mathrm{b}}$ & $24.75 \pm 5.32^{\mathrm{b}}$ & $441.25 \pm 206.15^{\mathrm{a}}$ \\
\hline $301-600$ cows & $437 \pm 8^{\mathrm{c}}$ & $25.83 \pm 4.90^{\mathrm{c}}$ & $29.42 \pm 4.90^{\mathrm{c}}$ & $412.68 \pm 159.18^{\mathrm{a}}$ \\
\hline$>600$ cows & $956 \pm 380^{\mathrm{d}}$ & $28.49 \pm 4.71^{\mathrm{d}}$ & $32.24 \pm 4.83^{\mathrm{d}}$ & $340.89 \pm 133.22^{\mathrm{a}}$ \\
\hline
\end{tabular}

a, b, cd Groups with different superscripts differ significantly $(p<0.05)$

TABLE 5. Milk production parameters according to milking parlour types $(n=417)$

\begin{tabular}{|l|c|c|c|c|}
\hline & $\begin{array}{c}\text { Average cow } \\
\text { number }\end{array}$ & $\begin{array}{c}\text { Average daily milk } \\
\text { production per cow (kg/day) }\end{array}$ & $\begin{array}{c}\text { Average daily milk } \\
\text { yield (kg/day) }\end{array}$ & $\begin{array}{c}\text { Average SCC } \\
\left(\times 10^{3} \text { cell/mL) }\right.\end{array}$ \\
\hline Herringbone & $301 \pm 246^{\mathrm{a}}$ & $22.60 \pm 6.12^{\mathrm{a}}$ & $26.18 \pm 6.14^{\mathrm{a}}$ & $429.24 \pm 189.74^{\mathrm{a}}$ \\
\hline Parallel & $656 \pm 281^{\mathrm{b}}$ & $27.96 \pm 5.13^{\mathrm{b}}$ & $31.76 \pm 5.18^{\mathrm{b}}$ & $349.80 \pm 154.13^{\mathrm{a}}$ \\
\hline Carousel & $900 \pm 351^{\mathrm{c}}$ & $27.68 \pm 5.03^{\mathrm{ab}}$ & $31.35 \pm 5.10^{\mathrm{ab}}$ & $324.26 \pm 150.48^{\mathrm{a}}$ \\
\hline Other & $616 \pm 367^{\mathrm{b}}$ & $25.68 \pm 5.85^{\mathrm{ab}}$ & $29.28 \pm 5.90^{\mathrm{ab}}$ & $378.00 \pm 176.54^{\mathrm{a}}$ \\
\hline
\end{tabular}

a, bc Milking parlour types with different superscripts differ significantly $(p<0.05)$ 
Tyapugin et al. (2015) compared three types of milking technologies (pipeline, parallel milking parlour, and robot) in terms of milk quality, and on those farms that used pipeline milking the viable cell count $\left(18,000 \mathrm{CFU} / \mathrm{cm}^{3}\right)$ was 1.5-times higher compared to those that used parallel milking parlour $\left(11,500 \mathrm{CFU} / \mathrm{cm}^{3}\right)$ and three times higher compared to those that used robot milking $(6,200$ CFU/ $\mathrm{cm}^{3}$ ). The somatic cell count averaged to $279,000 /$ $\mathrm{cm}^{3}$ in pipeline, $281,600 / \mathrm{cm}^{3}$ in parallel and $195,600 / \mathrm{cm}^{3}$ in robot milking systems. The lowest milk fat content ( $3.75 \%$ ) was measured in pipeline milking system, while it reached $3.83 \%$ in parallel and $3.88 \%$ in robot milking systems. In line with this result, Toušová et al. (2014) showed that the robot milking resulted in a higher milk fat content $(+0.16 \%, p<0.01)$ and higher milk protein content $(+0.06 \% ; p<0.01)$ than the traditional milking parlour. Further studies also confirmed that the daily milk production is higher and the SCC is lower with robotic milking compared to the traditional herringbone milking parlour (Bogucki et al., 2014; Petrovska and Jonkus, 2014; Svennersten-Sjaunja and Pettersson, 2008).

In Latvia the prevailing loose housing dairy farms mostly use two technologies - the herringbone and the carousel milking parlours (Priekulis and Kurgs, 2010). Both technologies were used on intensive farms where the average milk yield was $8,100 \mathrm{~kg}$, while for those having carousel milking parlours was $8,600 \mathrm{~kg}$. In Hungary carousel parlour is used on those farms where the cow number is more than 300 .

Our results show that the type of milking parlour is related to milk quality, and herringbone parlours, which were associated with the poorest milk quality, are mostly used in older milking systems. At the same time, larger cow number enables the farms to install newer milking systems (e.g. carousel), which might have a beneficial impact on both the milk production and quality (Nipers et al., 2016).

\section{Conclusions}

The dairy herd size in Hungary has a huge range from less than 10 cows to more than 2,700 cows. Large differences could also be observed in the milking technology (e.g. parlour type, number of milking stalls and daily milkings) and the milk production parameters (e.g. daily milk yield, SCC) between the farms. However, the majority of the surveyed farms still use herringbone parlours, while over 600 cows the parallel and carousel milking systems also play a significant role. Our findings show that the herd size has a greater impact on the milk production parameters than the type of milking parlour. The larger dairy farms may have better and newer housing, feeding conditions, and milking technologies, which could allow for higher milk production, however the average SCC was high in all size groups.

\section{Acknowledgements}

The Project was supported by the European Union and co-financed by the European Social Fund: (1) EFOP-3.6.1-16-2016-00024 "Innovations for Intelligent Specialisation on the University of Veterinary Science and the Faculty of Agricultural and Food Sciences of the Széchenyi István University Cooperation”; (2) EFOP-3.6.2-16-2017-00012 “Development of a product chain model for functional, healthy and safe foods from farm to fork based on a thematic research network"; and (3) EFOP3.6.3-VEKOP-16-2017-00005 "Strengthening the scientific replacement by supporting the academic workshops and programs of students, developing a mentoring process". 


\section{Povezanost tehnologije mužnje, veličine stada i parametara proizvodnje mlijeka na konvencionalnim farmama mliječnih goveda}

\section{Sažetak}

Cilj studije bio je ispitati tehnologiju mužnje i analizirati povezanost vrste mužnje, veličine stada i parametara proizvodnje mlijeka na farmama mliječnih goveda. Tehnologija mužnje ispitivana je korištenjem upitnika na 417 stada u Mađarskoj koja je sačanjavalo 177.514 krava u 2017. godini te je uspoređena s njihovim službenim podacima o proizvodnji mlijeka. Anketirana poljoprivredna gospodarstva razvrstana su prema veličini (1-50, 51-300, $301-600$ i >600 krava) kao i vrstama mužnje (riblja kost, paralelno stajališta, rotolaktor i drugi). Odnosi su analizirani multivarijantnim linearnim modelima, one-way ANOVA i Fisherovim testom. Parne usporedbe obavljene su Tukeyevim post-hoc testovima. Prevladavajući tip mužnje na farmama bila je riblja kost (71,0 \%), ali na većim gospodarstvima povećana je pojava paralelnih stajališta i rotolaktora $(p<0,001)$. Broj jedinica za mužnju po farmi povećavao se $s$ veličinom stada $(p<0,001)$. Farme $s$ izmuzištima u obliku riblje kosti imale su značajno manji broj muznih jedinica nego one $s$ paralelnim stajalištima $(p=0,022)$ i rotolaktorom $(p<0,001)$, a krave su se muzle uglavnom dva puta, dok su se u rotolaktoru muzle uglavnom tri puta dnevno. Kako se povećavala veličina stada, povećavao se i dnevni prinos mlijeka $(p<0,001)$ ali i dnevna proizvodnja mlijeka po kravi $(p<0,001)$. Veličina stada bila je povezana s brojem somatskih stanica $(p<0,001)$. Tip izmuzišta pokazao je značajnu povezanost $s$ dnevnim prinosom mlijeka $(p=0,039)$, a mliječne jedinice sa sustavom za mužnju riblja kost imale su najnižu kvalitetu mlijeka. Rezultati istraživanja pokazuju da veličina stada ima veći utjecaj na parametre proizvodnje mlijeka u odnosu na tehnologiju mužnje.

\section{Ključne riječi: mljekara, tehnologija mužnje, veličina stada, proizvodnja mlijeka, broj somatskih stanica}

\section{References}

1. Béri, B. (2011): Milking, feeding and drinking technology in cattle breeding (in Hungarian). In B. Béri (Ed.) Tartástechnológia, 20-27.

2. Bogucki, M., Sawa, A., Neja, W. (2014): Effect of changing the cow milking system on daily yield and cytological quality of milk. Acta Sci. Pol., Zootechnica 13 (4), 17-26.

3. Edwards, J.P., O’Brien, B., Lopez-Villalobos, N., Jago, J.G. (2013): Milking efficiency of swingover herringbone parlours in pasture-based dairy systems. Journal of Dairy Research 80 (4), 467-474. https://doi.org/10.1017/S0022029913000393

4. Fahim, A.D., Kamboj, M.L., Bhakat, M., Mohanty, T.K., Gupta, R. (2018): Preference of side and standing in relationship with milking characteristics and temperament score of crossbred dairy cows in an $8 \times 2$ herringbone milking parlour. Turkish Journal of Veterinary and Animal Sciences 42 (1), 49-54. https://doi.org/10.3906/vet-1705-1

5. Halasa, T., Huijps, K., Østerås, O., Hogeveen, H. (2007): Economic effects of bovine mastitis and mastitis management: a review. Veterinary Quarterly 29 (1), 18-31.
6. Jago, J.G., Berry, D.P. (2011): Associations between herd size, rate of expansion and production, breeding policy and reproduction in spring-calving dairy herds. Animal 5 (10), 1626-1633.

https://doi.org/10.1017/S1751731111000516

7. Krpálková, L., Cabrera, V.E., Kvapilík, J., Burdych, J. (2016): Dairy farm profit according to the herd size, milk yield, and number of cows per worker. Agricultural Economics Czech 62 (5), 225-234. https://doi.org/10.17221/126/2015-AGRICECON

8. Nipers, A., Pilvere, I., Valdovska, A., Proskina, L. (2016): Assessment of key aspects of technologies and cow farming for milk production in Latvia. Engineering for Rural Development 15, 175-181.

9. O’Brien, B., Jago, J., Edwards, J.P., Lopez-Villalobos, N., McCoy, F. (2012): Milking parlour size, pre-milking routine and stage of lactation affect efficiency of milking in singleoperator herringbone parlours. Journal of Dairy Research 79 (2), 216-223.

https://doi.org/10.1017/S0022029912000088 
10. Ózsvári, L., György K., Illés B. Cs., Bíró. O. (2003): Quantification of economic losses caused by mastits on a large-scale Holstein-Friesian dairy farm (in Hungarian with English abstract). Magyar Allatorvosok Lapja 5 (125), 273-279.

11. Petrovska, S., Jonkus, D. (2014): Milking technology influence on dairy cow milk productivity and quality. Engineering for Rural Development, 89-93.

12. Pfützner, M., Ózsvári, L. (2017): The financial impact of decreased milk production due to subclinical mastitis in German dairy herds. Journal of the Faculty of Veterinary Medicine Istanbul University 2 (43), 110-115.

13. Priekulis, J., Kurgs, A. (2010): Economically most efficient equipment in milking parlours. Engineering for Rural Development 15, 93-96.

14. R Core Team: R: A language and environment for statistical computing. R Foundation for Statistical Computing. Vienna, Austria, 2018. URL: https://www.Rproject.org/

15. Rasmussen, M.D., Bjerring, M., Justesen, P., Jepsen, L. (2002): Milk quality on danish farms with automatic milking systems. Journal of Dairy Science 85 (11), 28692878. https://doi.org/10.3168/JDS.S0022-0302(02)74374-9

16. Rodrigues, A.C.O., Caraviello, D.Z., Ruegg, P.L. (2005): Management of Wisconsin dairy herds enrolled in milk quality teams. Journal of Dairy Science 88 (7), 2660-2671. https://doi.org/10.3168/JDS.S0022-0302(05)72943-X
17. Lenilson da Fonseca, R., Lopes, L.S., Simioni, F.., Silva, A.S., Schonell, E.P., de Carvalho, J.R.R. (2015): Milk quality of properties with different technological standards. Bioscience Journal 31 (6), 1760-1770. https://doi.org/10.14393/BJ-v31n6a2015-26340

18. Seres, L., Ózsvári, L. (2014): The impact of three milkings a day on the production parameters and profitability in a large-scale Holstein-Friesian dairy herd (in Hungarian with English abstract). Magyar Allatorvosok Lapja 1 (136), 21-26.

19. Svennersten-Sjaunja, K.M., Pettersson, G. (2008): Pros and cons of automatic milking in Europe. Journal of Animal Science 86 (13), 37-46. https://doi.org/10.2527/jas.2007-0527

20. Toušová, R., Ducháček, J., Stádník, L., Ptáček, M., Beran, J. (2014): The comparison of milk production and quality in cows from conventional and automatic milking systems. Journal of Central European Agriculture 15 (4), 100-114. https://doi.org/10.5513/JCEA01/15.4.1515

21. Tyapugin, E.A., Tyapugin, S.E., Simonov, G.A., Uglin, V.K., Nikiforov, V.E., Serebrova, I.S. (2015): Comparative evaluation of technological factors affecting milk production and quality with various milking technologies. Russian Agricultural Sciences 41 (4), 266-270. https://doi.org/10.3103/S1068367415040199 